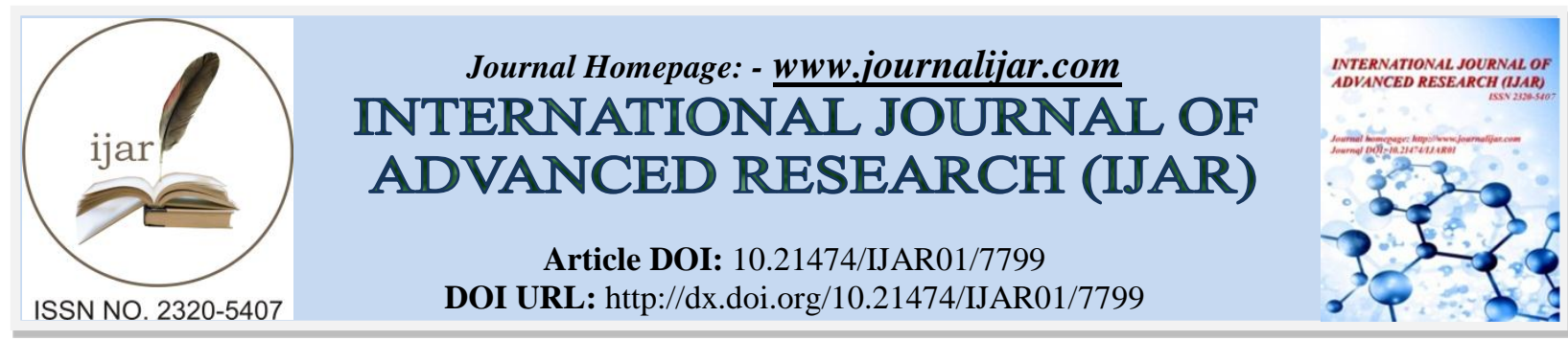

RESEARCH ARTICLE

\title{
AN INTERPRETIVE STUDY OF OPEN AND DISTANCE LEARNING STAKEHOLDER'S DEFINITIONS OF THE QUALITIES OF A GOOD TEACHER IN SELECTED SCHOOLS OF LUSAKA DISTRICT, ZAMBIA.
}

Lynette Hambulo, Emmy H. Mbozi and Wilmur Simatimbe

\section{Manuscript Info}

\section{Manuscript History}

Received: 3 August 2018

Final Accepted: 5 September 2018

Published: October 2018

Keywords:

Open and Distanceclasses, Adult

Learner and Good Teacher.

\begin{abstract}
This paper focuses on the definitions of the qualities of a good teacher by three categories of stakeholders to open education: learners, teachers and education administrators. The paper examines stakeholder's definitions of the qualities of a good teacher in Open and Distance Learning (ODL) classes in selected schools of Lusaka District. An interpretive phenomenological research design was used and data was collected from open and distance learning students and teachers using in-depth interviews.The researchers felt that an interpretive study would help them understand the phenomenon of a good teacher from the perspective of those experiencing it, in this case; the learners, teachers and administrators. One of the reasons for this study was to explore the possible divergences in the meanings of a good teacher among the stakeholders. Data was also collected from Education Standards Officers-Open and Distance Learning (ESO-ODL) and head teachers using in-depth interviews, these represented the category of education administrators and were responsible for ensuring good standards in the open and distance learning classes. The paper analyses student's definitions of the qualities of a good teacher, provides a description of teacher perceptions of the qualities of a good teacher, explains education administrators' views of the qualities of a good teacher and finally suggests actions that would develop good teachers of adult learners in Open and Distance Learning Classes.
\end{abstract}

Copy Right, IJAR, 2018. All rights reserved.

\section{Introduction:-}

A number of studies that have been conducted looked at the qualities of a good teacher from a non interpretivist perspective. This has led to a focus away from the learners descriptions of a good teacher. There was therefore a need to understand phenomenon from the perspective of those experiencing it, and so there was need to interpret the meaning of a good teacher to the open learners. The researchers felt that in order to understand what a good teacher was one needed to look at all the three perspectives of the stakeholders in the open classes and these were the learners, the teachers as well as the administrators. Previous studies had assumed that there was harmony among the stakeholders' meanings of the qualities of a good teacher. The reason for this interpretive study was to examine the possible divergences in the way stakeholders' perceived a good teacher. 
Walker (2008) conducted a longitudinal qualitative quasi research on in-service and pre-service teachers' opinions of the characteristics of an effective teacher. This study looked at the opinions of student teachers' of the characteristics of a good teacher. It concentrated on one angle of opinions, those of student. The current study incorporated other stakeholders such as the teachers as well as administrators. Kayungwa (2002) also conducted a study on the qualities of an effective teacher as perceived by grade twelve pupils and teachers. His study was from a non-interpretive perspective, he analysed the differences in opinion of boys and girls of whom they considered to be a good teacher. Kayungwa's study looked at perceptions of a good teacher by pupils in formal classes found in formal schools. However, the current study had a different standpoint in that the researchers sought to interpret the meanings of a good teacher as perceived by the adult learners who had been incorporated in formal schools whose classes were composed of older and younger learners (teenagers) and were taught by the teachers who had not been trained in adult education principles.

\section{Open and Distance Classes}

The Zambian government recognises education as a basic human right that is vital for both personal and societal development. The government has prioritized education with an overarching goal of increasing access to education. In its Seventh National Development Plan (7NDP) whose theme is "accelerating development efforts towards the vision 2030 without leaving anyone behind" the government has prioritise access to quality, equitable and inclusive education. (Seventh National Development Plan 2017).The national policy on education: Educating Our future and other policy documents reaffirm the Zambian government's commitments to providing education as a human right and its conviction that education and training are necessary pre conditions for human and economic development (Ministry of education, 1996 cited in Siaciwena and Lubinda, 2008).

Zambia's education system consists of early childhood education (ECE), primary, secondary and professional or tertiary levels. In addition to the formal system, there are is a non-formal education system that operates to serve among others, displaced persons, school aged children who have either dropped out of school or have never attended formal school, geographically isolated children, street and working children as well as adults that want to be literate. The Ministry of General Education (MOGE) has equally recognised Open and Distance Learning as modes of education (Educational Statistical Bulletin: 2016). One of the Ways in which Zambia is promoting human and economic development through the Ministry of Education is through Open and Distance Learning (ODL) classes supervised by the Directorate of Open and Distance Education (DODE). This accords learners who might have failed and dropped out of Secondary school a chance to getback and continue from where they had left from regardless of their age.

The focus of the Ministry of General Education and the Directorate of Open and Distance education in particular, is to provide more opportunities for the out of school population to access quality education. The main functions include: Providing and facilitating non segregative distance learning programmes, Promote community participation in the provision of education, Promote literacy and distance learning in the nation, Facilitate and provide education through the non- formal sector and Coordinating the provision of correspondence studies. The vision of the Directorate is line with that of the Ministry of General Education, which is to provide quality, lifelong education for all, which is accessible, inclusive, equitable and relevant to individual, national and global needs and value systems. This paper focuses on open learning at secondary school level where adult learners go to school to learn in formerly organised classes. These classes are referred to as open learning classes or DODE classes. Learners in these classes vary in age depending on the point in life when they realised the need for education and got back to school. Some of them are married with children while others are younger who might have failed but quickly went back to continue where they had left from. These classes are conducted in the afternoon when the regular students have knocked off creating space for them. It has to be noted here that the learners in these classes regardless of their age wear uniforms just like regular learners and are taught by the same teachers who teach in regular classes. The study focused on the perceptions of stakeholders on the good qualities of a teacher of adult learners in these open learning classes.

\section{The Adult Learner}

Before discussing an adult learner, it is important that we establish who an adult is. An adult is an individual who is biologically, psychologically, chronologically and sociologically mature and is considered as such by the community that he/she lives in. Kamwengo (2006) explains that adults are bigger than children, who display basic attributes of maturity and behaviours that are characteristic of persons accorded the status of adults in their society. An adult learner is thus a person that is no longer a child pursuing knowledge intended to change his or her life 
situation. Adults don't learn like children, they are more discerning in what they are willing to learn. They need to see more clearly how that what they are learning is much more useful than it is for children (www.phoenix.ed). Learners in open classes are mostly mature people who decide to continue with their secondary education from where they had left. They may have dropped out of school due to reasons such as teenage pregnancy, early marriage, financial difficulties, failure and sickness.These learners are therefore adult learners whose reasoning is different from that of younger learners because at their stage of life they have a wide-range of responsibilities such as that of being a parent, wife, bread winner, church leader and community member. Adult learners have goals to achieve, they go back to class in order to pick up from where they had left and are determined to complete their secondary education successfully. Some of these learners are married and have children who could be age mates with some of their class mates. Some of these learners could be of the same age or older than their teachers. The dynamics of these classes are that they cut across age simply because learners decide to get back to school at different ages. For example, some decide to get back early enough when they are still in their adolescent ages while others go back when they are well advanced in age.

Ideally the adult learners are expected to learn in adult education classes where they are treated as adults and taught by adult educators who are trained to handle adult learners. According to Lindeman (1926), the whole of life is learning, and therefore education can have no ending. This new venture is called adult education, not because it is confined to adults but because adulthood, maturity, defines its limits. It is therefore, assumed that at this level adults learners have certain expectations from their teachers. It was for this reason that this study sort to interpret the adult learner's perceptions of the qualities of a good teacher in comparison with the perceptions of other stakeholders.

Kidd points out that ignorance still abounds concerning the learning of adults. It is not fully understood why it is that some people will put forth effort, will extend themselves and their powers, will try, will risk, while others are more resistant, more wary, are slow to start and quick to give up. The latter are showered with advice and quickly classified as apathetic, or lazy, or not well motivated. This is much easier to do than it is to understand or help people become effective learners (Kidd: 1973). Adult educators should therefore encourage and enable adult learners to discover themselves, belive in themselves and desire to further their education as opposed to condeming and demeaning them when they do not perform to expectation.

\section{Good teacher}

Being a good teacher is more than just depositing content knowledge to the learners. The process of teaching is more problematical because teaching is a complex and multi-dimensional process that requires deep knowledge and understanding in a wide range of areas and the ability to synthesise, integrate and apply this knowledge in different situations, under varied conditions and with a wide diversity of groups and individuals (Hollins 2011). The teaching process is even more complicated when the learners are adults but attending formal schools in the same classes with the younger learners or adolescents. It is not an easy thing to be a teacher of such a class because one needs to have skills of handling both young and adult learners at the same time. Adults learn differentlyfrom children, adults come to the classroom with experience, the have goal oriented, they have self-respect, they have several responsibilities and are performance focused. Adults desire to be treated with the respect that they deserve, and so for effective learning to take place the teacher has to be aware and sensitive to all these factors. A good teacher of this kind of a mixed class needs to be balanced for effective learning for all the age groups to takes place.

To be a good teachers is to be many things at the same time, it entails being able to change roles in response to different learner needs and to different situations. A good teacher is a counsellor to the learner who is going through psychological and emotional challenges. A good teacher is a tutor to one who is having challenges in the subject matter, he/she should have the patience to accommodate the slow learner at the same time not slow down the fast learner. A good teacher is a comforter to one who is going through trying moments from his/her home, the teacher realises that learners go through various challenges and is therefore sensitive enough to identify the strange behaviour in the learners. Such a teacher takes time to find out the cause of the change in behaviour and come in handy to help the learner. According to Bullock (2015) a good teacher is more than just an educator, the characteristics that make a teacher good are complex and extensive. Adult learning theory has developed a series of characteristics that define the difference between adult learners and traditional learners. These characteristics make adult learners comfortable and learn freely without feeling intimidated or discouraged.

Being a good teacher is not an easy task, it comes through experience and observation over the years. With time the teacher learns to be the answer to the learners' needs at the same time meet the administrator's expectations. One 
learns that punishing or ridiculing offenders is not the solution but finding out the cause of that maladjustment and trying to find solution to the problem which might just turn out to be counselling as opposed to punishment. Over the years the teacher gains mastery of the subject content and discovers better ways of presenting the content to the learners which in turn enhances effective teaching and learning. A good teacher must remain a lifelong learner, enthusiastic to seek and adopt to new knowledge. A good teacher is one who is thirst for knowledge and eager to be a continuous researcher. This enables such a teacher to always be on top of things and ahead of his/her learners. A good teacher has the content of his subject on the figure tips. Such a teacher inspires the learners as they look forward to learning something new from their capable teacher all the time. The teacher is expected to be systematic, dedicated and punctual. These attributes are associated to the virtue of having undergone training as they are found in the pedagogical lessons. Therefore, every good teacher is expected to possess them.

One of the best quality of teaching is having knowledge about the learner, understanding their stage of life and appreciating the challenges they face. Hollins (2011) explains that the most important aspect of good teaching is how well the teacher knows the learner. He further clarifies that teachers need to know learners as individuals; as members of the social and cultural groups; as learners at a particular point in their academic, emotional, psychological and social development. When a teachers knows his/her learners he knows their various needs; be it academic, psychological, emotional or physical. When the teacher understands the need of his learners and responds accordingly, he becomes relevant to those learners.

The teacher is key figure in the education system. The personal character of the teacher is associated with a combination of various attributes. The teacher should be sincere and honest, warm and friendly, dependable and respectable, tolerant and understanding, caring and compassionate. Learners learn by imitation and so the teacher's self-image is very important as it is mostly emulated by the learners. The teacher's character must be positive in order to save as a model of socially accepted pattern of behaviour.

\section{Research Problem}

Individuals who might have dropped out of school or may have discontinued their learning for various reason but are interested in continuing their education at secondary school level are given a chance to do so in specific schools that offer open classes under the Directorate of Open and Distance Education (DODE). These learners attend classes referred to as open classes in the afternoon.

Due to the interruption in their education quite a number of them are adults rather than adolescents as is the case in formal education. A number of studies have been carried out such as that of Mutale (2010) which focused on opinions of adolescent learners in formal classes on the qualities of an effective teacher rather than adult learners. Kayungwa (2000) also focused on qualities of an effective teacher as perceived by grade 12 pupils. These pupils were in normal classes as opposed to open classes.

At the time of embarking on this study there was of dearth of research-based literature on the qualities of a good teacher of adult learners in open classes, let alone interpretive study based literature. It is for this reason that this study sort to examine the meanings of a good teacher from the perspective of three key categories of stakeholders to a learning situation: learners, teachers and administrators.

\section{Research questions}

The study sought to answer the following questions:

1. How do students define a good teacher of adult learners?

2. How do teachers define a good teacher of adult learners?

3. What are the educational administrators' expectations of a good teacher of adult learners?

\section{Methodology:-}

An interpretive phenomenological research design was used to interpret the meanings of the qualities of a good teacher by the learners, teachers and administrators. In-depth interviews were conducted with the learners, teachers as well as administrators in order to get information on their perceived qualities of a good teacher of learners in open classes. The researchers opted for the in-depth interviews because there was need to stimulate response from the respondents through conversation. A tape recorder was used during the interviews in order to ensure accuracy. 
The population comprised of all Secondary School Open Learners, all the teachers of ODL classes and all the administrators of ODL programmes in Lusaka district. A sample size of 36 respondents was used comprising of 20 learners from 3 secondary schools in Lusaka District. The learners were selected using purposive sampling procedures because the researchers were only interested in learners who were above 19 years of age. 10 teachers were also selected purposively from the 3 schools because the researchers were only interested in the teachers who were involve in teaching in open classes and the 6 administrators were conveniently selected.

The study used qualitative data analysis procedure. Qualitative data was analysed by categorizing, comparing, synthesizing and interpreting so as to provide explanations about the meaning of the qualities of a good teacher to stakeholders. Qualitative data was coded into etic and emic themes and presented as summaries.

The researchers sought permission from the District Education Board Secretary (DEBS) to conduct interviews with the school managers, teachers as well as the learners. At the stations (schools) the researchers sought permission from the school managers before interviewing the teachers and the learners. During the research, confidentiality was maintained and no names of the respondents were written. Instead, numbers (such as 1,2,3 ..) were used. A consent form was signed by the respondents to show willingness to participate in the research. The findings of this research where not used for any purpose other than for academic use. Comprehensiveness was upheld as all the information gathered was obtained the way it was given and narrated as such.

\section{Results:-}

The findings were based on the research questions which the study sought to answer.

\section{Students' definitions of the qualities of a good teacher}

The findings from the learners were diverse and numerous, the study ranked the qualities in order of popularity or the ones that were most frequently mentioned by the respondents. When asked who to them was a good teacher and what that meant, the students identified lists of qualities that they felt made one a good teacher. The qualities ranged from professional to personal attributes, the list was therefore categorised into themes of qualities of a good teacher as perceived by the adult learners. The responses were then arranged in order of frequency, the most frequent qualities were taken as the most popular qualities of a good teacher.

Table 1:-Students definitions of the qualities of a good teacher

\begin{tabular}{|c|c|c|c|}
\hline $\begin{array}{l}\text { Emic definition of a } \\
\text { good teacher }\end{array}$ & $\begin{array}{l}\text { Emic explanations by } \\
\text { learners }\end{array}$ & $\begin{array}{l}\text { Emic explanations by } \\
\text { teachers }\end{array}$ & $\begin{array}{l}\text { Emic explanations by } \\
\text { administrators }\end{array}$ \\
\hline $\begin{array}{l}\text { understand the } \\
\text { learners }\end{array}$ & $\begin{array}{l}\text { Knows that some people are } \\
\text { slow learners, gives chance } \\
\text { for everyone to understand. } \\
\text { Able to know the age } \\
\text { difference, knows how to } \\
\text { handle adults. } \\
\text { One who understands us } \\
\text { and advises us as our parent }\end{array}$ & $\begin{array}{l}\text { Able to identify learning } \\
\text { abilities of learners so as } \\
\text { to know the pace to move } \\
\text { at }\end{array}$ & $\begin{array}{l}\text { Teachers must look at these } \\
\text { learners not as adults but as } \\
\text { learners likewise the learners } \\
\text { must respect their teachers } \\
\text { regardless of their age because } \\
\text { at the end of the day they need } \\
\text { to pass the exam }\end{array}$ \\
\hline Uses good language & $\begin{array}{l}\text { Not those who shout } \\
\text { Not sarcastic } \\
\text { Calm and soft }\end{array}$ & $\begin{array}{l}\text { Should be careful in } \\
\text { language so as not to } \\
\text { injure learners }\end{array}$ & $\begin{array}{l}\text { Tempers should be controlled } \\
\text { Should not use vulgar language }\end{array}$ \\
\hline Friendly & $\begin{array}{l}\text { One whom pupils can get } \\
\text { close to } \\
\text { Always recognises pupils } \\
\text { outside the classroom } \\
\text { Makes us free to ask } \\
\text { questions } \\
\text { We can joke and laugh } \\
\text { together }\end{array}$ & $\begin{array}{l}\text { Those who are old take } \\
\text { them as colleagues }\end{array}$ & $\begin{array}{l}\text { Must be social, learners should } \\
\text { be free with their teacher } \\
\text { Must interact with fellow } \\
\text { teachers and consult were } \\
\text { necessary }\end{array}$ \\
\hline Has a heart to teach & $\begin{array}{l}\text { They show us the pupils } \\
\text { that they enjoy their job, not } \\
\text { like they are being forced }\end{array}$ & $\begin{array}{l}\text { Committed to work } \\
\text { Always punctual } \\
\text { One who is passionate for }\end{array}$ & $\begin{array}{l}\text { Must be available, not having } \\
\text { problems always and full of } \\
\text { excuses }\end{array}$ \\
\hline
\end{tabular}




\begin{tabular}{|c|c|c|c|}
\hline & $\begin{array}{l}\text { Some even say, me I am } \\
\text { getting paid, it's your own } \\
\text { fault if you fail } \\
\text { Have a heart to control } \\
\text { pupils when they are wrong } \\
\text { Committed }\end{array}$ & the job & Must not be forced to work \\
\hline Kind & $\begin{array}{l}\text { Takes time to know the } \\
\text { problems of the pupils } \\
\text { Not harsh } \\
\text { If I don't understand I ask } \\
\text { they should tell me } \\
\text { If I' am wrong they correct } \\
\text { me and punish me }\end{array}$ & $\begin{array}{l}\text { Is interested in the affairs } \\
\text { of the pupils } \\
\text { Is helpful to pupils with } \\
\text { problems }\end{array}$ & Gives counsel when need arises \\
\hline Patient & $\begin{array}{l}\text { Takes time to explain for } \\
\text { everyone to understand } \\
\text { Should have time for you, } \\
\text { not always busy }\end{array}$ & $\begin{array}{l}\text { Doesn't rush knowing } \\
\text { that some of these are } \\
\text { slow learners }\end{array}$ & $\begin{array}{l}\text { Moves at a pace that ensures } \\
\text { that all the learners are catered } \\
\text { for }\end{array}$ \\
\hline Approachable & $\begin{array}{l}\text { We can go to him/her to ask } \\
\text { questions and assistance. } \\
\text { Pupils should be able to go } \\
\text { to the teacher and feel at } \\
\text { home }\end{array}$ & $\begin{array}{l}\text { Pupils are free to talk to } \\
\text { that teacher }\end{array}$ & $\begin{array}{l}\text { Accommodating } \\
\text { Receptive } \\
\text { Learners should be free with } \\
\text { the teacher }\end{array}$ \\
\hline Motivational & $\begin{array}{l}\text { Encourages us to study } \\
\text { more } \\
\text { Gives morale to pupils to } \\
\text { look forward to learn } \\
\text { Encourages that you have } \\
\text { something in you and can } \\
\text { pass }\end{array}$ & $\begin{array}{l}\text { Talk positively about } \\
\text { subject } \\
\text { Encourage the learners to } \\
\text { work hard }\end{array}$ & $\begin{array}{l}\text { They must not be looked at as } \\
\text { failures } \\
\text { Encourages them to keep } \\
\text { pushing }\end{array}$ \\
\hline
\end{tabular}

What was observed was that the most frequent responses were on the personal attributes of the teachers as compared to the professional skills. Very few responses point to knowledge of subject content as a sign of a good teacher for example. The following themes emerged from the students responses on the qualities of a good teacher;

\section{Friendly}

The responses showed that the all the respondents felt that a friendly teacher was a good teacher. A friendly teacher to them was one who was approachable, open, welcoming, warm and accepting. This was a teacher a learner would walk up to and ask questions without fear of being turned away or ridiculed. A friendly teacher greeted the learners and smiled at them, talked to them freely and was interested in their wellbeing. The following ware responses from learners;

"A good teacher should be good friends with the pupils, identifies the reasons why his or her pupils behave in such a manner, in short she notices pupils with problems. A pupil should be able to go to a teacher and feel at home, like that we can be free to open up to that teacher."

Another respondent said;

"A teacher who smiles in class. I enjoy the lesson when a teacher smiles and is in a good moody and I remember what I learnt"

\section{Patient}

The learners pointed out a patient teacher as a good teacher. A patient teacher was one who did not condemn the learners when they fail to achieve according to his/her expectations. A teacher who is patient explains over and over, guides the learners and encourages them to try again. One respondent had this to say;

"A good teacher makes you understand, he does not rush, if you ask a question they answer it, if not there and then, they still remember to come back to your question and answer it. When I fail they show the correct way and encourage." 


\section{Articulate}

A good teacher according to the responses was one who was articulate, eloquent and expressive. This teacher was also seen to be captivating. He or she was able to explain clearly for the learners to understand. He/she was able to deliver the content in a systematic and simple way for the learners to understand. One of the learners had this to say;

"A good teacher is one who gives knowledge and makes sure the knowledge is digested, he explains so well that we are able to understand and if we haven't understood he would repeat for us.

\section{Knowledgeable}

The learners perceived a teacher who had content knowledge as a good teacher. To the learners, a knowledgeable teacher researched a lot and had a lot of information to give to the learners on a specific subject. One respondent had this to say;

"A good teacher is well prepared for the lesson, the read enough. Not teaching on things they are not sure about."

\section{Understanding}

The majority of the learners interviewed perceived a teacher who understood his/her learners as a good teacher. A good teacher was one who understood the individual learners and appreciated them as individuals and that each individual was different in personality and intellectual ability. One of the respondents said;

"A good teacher understands that some are slow to understand. The teacher encourages you to work hard and does not embarrass you. Not when one asks a question they tell you to ask your friends who might have not understood as well."

\section{Motivational}

A motivational teacher was one who encouraged learners to believe in themselves and to keep pushing and that they would make it. This teacher believed in the learners and showed it by giving them talks that helped the learners to have a high self-esteem.

"A good teacher is one who encourages you to realise that you have something in you and that you can pass."

\section{A teacher who is not sarcastic}

The learners appreciated a teacher whose language was good. They felt that a teacher who selects words that do not injure the learners was a good teacher. This was one of the responses;

"One who does not shout at you when you make a mistake, not correcting you with bad language. Some teachers do not care that there are parents and old learners in their class, the language they use is bad especially when you give a wrong answer. That makes you to even stop trying."

\section{Ensures work is done and gives feed back}

A good teacher was seen to be one who insured that work was done. Such a teacher marked the work and gave feedback to the learners for them to see how they were performing in that topic. One respondent said

"Makes sure that you do his work by all means. If you don't do the work you get punished. They should also mark the work to avoid learners repeating the same mistakes in the exam"

\section{Role model}

A good teacher was one that learners can looked up to and and were inspired to be such. He/she was a good example to the learners in conduct or in the way he/she carried him/herself. A good teacher was one who was modesty. One learner said;

"One whom I can look up to, he or she should be a role model, one who shows that he enjoys his job, not like he is being forced."

\section{Another learner said;}

"How they present themselves matters, dress code, they should dress decently."

\section{Focusses on most important topics}

The learners identified a teacher who focused on most important topics as a good teacher, they said they needed to learn those things that would come in the exams and not just anything. A good teacher concentrated on what was important.

"They teach what is likely to come in the exam, not teaching anyhow and everything." 


\section{Teacher definitions of qualities of a good teacher}

Questions to establish who a good teacher was to the teachers were asked, the information was important for the researchers because it would help to find out what kind of a teacher the teachers themselves considered to be good.The responses were coded into themes which were grouped into two categories; professional skills and personal attributes.

The responses were as shown in the table below

Table 2:-Teacher definitions of qualities of a good teacher

\begin{tabular}{|c|c|c|}
\hline & Good Teacher & Bad Teacher \\
\hline Category & Quality & Quality \\
\hline Professional Skills & $\begin{array}{ll}\checkmark & \text { Knowledgeable } \\
\checkmark & \text { Simplifies lessons } \\
\checkmark & \text { Evaluates performance } \\
\checkmark & \text { systematic } \\
\checkmark & \text { Interactive } \\
\checkmark & \text { Resourceful } \\
\checkmark & \text { Dedicated }\end{array}$ & $\begin{array}{ll}\checkmark & \text { Fails to deliver content } \\
\checkmark & \text { Boring/not eloquent } \\
\checkmark & \text { Always late } \\
\checkmark & \text { Lacks creativity }\end{array}$ \\
\hline Personal Attributes & $\begin{array}{ll}\checkmark & \text { Role model } \\
\checkmark & \text { Motivational } \\
\checkmark & \text { Patient } \\
\checkmark & \text { Tolerant } \\
\checkmark & \text { Uses good language }\end{array}$ & $\begin{array}{ll}\checkmark & \text { Sarcastic. } \\
\checkmark & \text { Harsh } \\
\checkmark & \text { Inconsiderate } \\
\checkmark & \text { Not passionate } \\
\checkmark & \text { Not flexible }\end{array}$ \\
\hline
\end{tabular}

Source: Field data 2017

What was noticed was that the most frequent responses for the teachers were on the professional skills as compared to the personal attributes.The following themes emerged from the teachers responses as the qualities of a good teacher;

\section{Knowledgeable}

All the teachers interviewed mentioned a knowledgeable teacher as a good teacher. For them a knowledgeable teacher was one who had the content matter and was adequately prepared for his or her class by doing enough reading or research on the topic to be taught. One respondent had this to say;

"A teacher should fully prepare for the learners so that he or she is able to come up with various ways of teaching by coming up with activities which can make the learners understand. A teacher should read more books not just relaying on one book. In short a teacher should be a researcher."

\section{Simplifies lessons}

The responses revealed that the respondents perceived a teacher who made work simpler for the learner as a good teacher. One respondent said;

"One who makes work easier for the learners to understand and simplifies the content by way of modifying the content which seemed harder before to look simpler."

\section{Evaluates learner performance}

A teacher who evaluates the performance of the learners was considered to be a good teacher by the respondents. The teachers felt that a teacher who evaluates the learners is able to know the performance of the learners.

"A good teacher assesess the learners before the exams to see if they understand what is taught. This could be done monthly or at the end of the topic."

\section{Systematic}

The teachers felt that a teacher who presented the content in a logical manner was good one responded said; "Teaches systematically from simple to complex, from known to unknown. Not one who jumbos the work." 


\section{Interactive}

An interactive teacher for the teachers was one who was corroborated with fellow teachers. This teacher was able to consult when not clear about certain topics. Interactive also meant that the teacher was able to involve his learners in the class activities. One teacher said;

"A good teacher should be able to mix freely with other teachers especially those that are in the same department. By doing so they can consult on topics that they are not clear on."

"A teacher should be able to interact with the pupils, by that I mean, they should take interest in their learners and show concern about problems."

\section{Resourceful}

The response showed that a resourceful teacher was imaginative and creative. Able to teach a topic in a variety of ways with available resources. One science teacher said;

"A teacher should be creative, able to teach using different methods so as to make the lesson interesting. The teacher teaches practically, he doesn't wait for management to buy apparatus and specimen before he can conduct a practical lesson but can use things from the natural environment."

\section{Dedicated}

A dedicated teacher was perceived to be a good teacher by the teachers. A dedicated teacher loved his or her job. The teacher was passionate about their teaching profession and that could be seen in their commitment to work. They were always there and on time unless they had a major challenge.

"A good teacher has the learners at the centre of his or her heart. He can sacrifice for them, they are selfless."

\section{Role model}

The respondent described a good teacher as one who was a role model to the learners. One they would emulate and desire to be like them.

"A teacher who is a good example to the learners is a good teacher. A teacher should be morally upright so that pupils can emulate. Aaah.... I can give an example on dressing, a good teacher dresses modestly. The dressing speaks volumes about one's character"

\section{Motivational}

A teacher who motivates the learners was perceived as a good teacher by the respondents. This teacher encourages the learners to work hard and to aspire for greatness. One responded said;

"Should be motivating, talking about the subject that you teach in a positive way. Talk about those who have succeeded as examples than demotivating-like; this is hard you need to be serious but instead say, this is simple you can do it. These pupils should always be encouraged despite how hard the subject is."

\section{Patient}

A patient teacher was described as one who does not rush through the lesson, the teacher takes time to explain and ensures that the learners understand. A respondent had this to say;

"Since most of these learners had failed before, a good teacher reduces speed when teaching them otherwise they will not understand."

\section{Tolerant}

The respondents describe a tolerant teacher as a good teacher. A teacher who leaves room for the learners to be themselves. One of the respondents said;

"Sometimes learners can be a nuisance, they can put you off target so you need to have a big heart to survive and move on."

\section{Uses good language}

A good teacher was seem as one who did not use vulgar language to the learners. He was considerate of the words used so as not to offend the learners.

"A good teacher is not sarcastic especially that these are adults, one needs to mind the language to use." 


\section{Understands the learners}

Understanding was another quality that was explained by the teachers as a quality of a good teacher. They said that teachers should know most if not all of their learners and appreciate each individual's abilities. One respondent had this to say;

"A good teacher is one who is able to identify the abilities of the learners. This is important because it enables one to know the pace to move at in order to cater for all the pupils in that class. And each learner must be appreciated in whatever effort they make."

Administrators' expectations of a good teacher of learners in open classes

The following qualities were viewed as good for a teacher of adult learners by the administrators

\section{Resourceful}

The administrators identified a good teacher as one who was resourceful. One who was able to research and was ahead of time. One administrator said;

"A good teacher knows more than what the learners know, they should prepare adequately for their classes and be on top of things. You see madam, in this error there are learners that can Google and get information so the teacher should be ahead of time."

\section{Friendly}

The administrators described a friendly teacher as a good teacher. This teacher was receptive and sympathetic and took time talking to and helping the learners.

"Students must be free to come close to the teacher, when the teacher is harsh they will fear and the subject will be hated."

Another respondent said; "A teacher should be willing to go an extra mile to help learners"

\section{Tolerant}

Tolerance was identified as a quality of a good teacher. A teacher who was accepting of the learners as individual who have different abilities and temperaments.

"The teacher must be accommodating. The tempers should not be on the high side but they should be 'equilibriumed' so to speak to accommodate critical views from the learners"

\section{Self-disciplined}

A good teacher to the administrators was one who was morally upright. One respondent said;

"They must be treated as sacred in terms of, aaah... these are learners they must not be seen as wives. And the learners should not look at the male teachers as potential husbands."

\section{In control}

What came out from the responses was that a good teacher was one who had control over his or her class. He or she was one who was able to manage the class in terms of behaviour and maintaining order. One respondent had this to say;

"The teacher should command respect from the learners and ensure that the learners follow the rules of the class, the teacher should be able to instil discipline in the learners which helps learning to take place because without discipline no learning can take place."

\section{Consistent}

Consistence was perceived as a quality of a good teacher by the administrators. They pointed to the fact that a teacher should be available at all times.

"A good teacher is one who does not miss lessons anyhow, You know.....some teachers are in a habit of missing lessons, they always have excuses for missing class.. , a teacher should always be available unless they have a big problem.

\section{Discussion:-}

The study revealed that the most frequent responses form the students were based on personal attributes of the teachers as compared to their professional skills? A friendly teacher was perceived as a good teacher by the majority of the learners. According to the students, a friendly teacher was one who was approachable, open, welcoming, 
warm and accepting. This was a teacher a learner would walk up to and ask questions without fear of being turned away or ridiculed even outside the classroom. A friendly teacher greeted the learners and smiled at them, talked to them freely and was interested in the wellbeing of his or her learners. The learners stated that they enjoyed the lessons of a teacher who smiled in class and that helped them to remember the lesson. This was in line with that of Fosen (2016) who observed that the main strategy for developing good teachers' relationships was getting to know students in terms of their academic performance, interests and their personal problems. He further stated that teachers gained this knowledge through engaging students in conversation, not only in the classroom, but also in the school hallways and outside of school. Hollins (2011) explains that the most important aspect of good teaching is how well the teacher knows the learner. He further clarifies that teachers need to know learners as individuals; as members of the social and cultural groups; as learners at a particular point in their academic, emotional, psychological and social development. Teachers should therefore, endeavour to be selfless for the sake of their learners that enables learners to learn freely without fear and as such they begin to love their teacher. When a student loves the teacher the chances that they will love his subject too are high and when they love the subject they concentrate and thereby increasing the chance of high performance in that subject.

It was however observed that from the minority who pointed to professional attributes as qualities of a good teacher, a good number described a knowledgeable teacher as a good teacher. The knowledgeable teacher was one who had enough knowledge about his subject content. Teachers must know the subjects they teach and how to teach these subjects to the students. Knowledge can be acquired through various ways such as research, consultation and observation of expert teachers. A good teacher therefore is a constant learner, this enables him to be on top of things in that it boasts confidence and that of the learners. The role of the teacher is to impart technical knowledge to the students. This therefore means that in order for a teacher to fulfil his or her duties, he or she must do the best to ensure that the learners are given the needed, correct and accurate knowledge.

On the other hand, the most frequent responses from the teachers pointed to professional skills as compared to the personal attributes. All the teachers interviewed mentioned a knowledgeable teacher as a good teacher. For them a knowledgeable teacher was one who had the content and was adequately prepared for his or her class by doing enough reading or research on the topic to be taught. The meanings for a knowledgeable teacher were similar as those of the learners. For the teachers it is their role to impart knowledge to the learners and as such all of them believed that a good teacher was one who knew what he she was doing. According to Saleemi (undated), the foremost duty of the teacher is intellectual/creative development of the learners. This explains why teachers are so focused on imparting knowledge than on being friendly. The ultimate goal for the teachers was to see to it that their learners performed well in the class and in final examinations. However, a teacher should not forget that he/she also has a duty of developing ethical dimensions of the students which include, motivation, character, self-esteem and civic responsibility. (Saleemi undated)

For the administrator a knowledgeable and resourceful teacher was considered to be good. The results showed that administrators were result focused and so most of the responses were pointing to professional attribute of the teacher as compared to personal attributes. They expected the teacher to know his content and to be resources where materials were lacking, to be in control of the class, self-disciplined and consistent. However administrators acknowledge the fact that it was important for the teacher to be friendly and tolerant.

\section{Conclusions and recommendations;-}

It was established that meanings of a good teacher among the stakeholders were congruent in many aspects. For example, a knowledgeable, kind, friendly, tolerant and many others meant the same for all the stakeholders.

However there were a few divergences in the meanings such as of an "understanding teacher". To the learners, a teacher who understood his learners was one who realised that his class had learners of different ages and should know how to handle them as adults. These were adult learners who felt that they were at times not treated with respect. Which made them to fear to participate freely for fear of be ridiculed in the presence of younger learners. For the teachers, a teacher who understood the learners was one who was able to identify differences in learner's abilities so that they could cater for both the faster and the slower learners. The administrators felt that a teacher should treat these learners equally without looking at them as adults because the teacher is the expert person who should ensure that the learners pass at the end of the day. The administrators and teachers did not care so much about the issue of the age of the learners. They were more result oriented contrary to Malcom Knowles adult learning principles which stipulate that adult learners have a self-concept of being adults, are self-directed and are 
ready to learn. Adults thus desire to be seen and treated as adults. (Knowles 1980). This finding showed that teachers and administrators were oriented to pedagogical ways of teaching as opposed to andragogical principles. According to Knowles, andragogy is the art and science of helping adults learn and pedagogy is the art of teaching children. Teachers who teach such mixed classes should therefore learn to use both principles in order to balance their teaching and avoid offending the learners.

\section{The study recommends the following:}

1. Teachers of Open Learning Classes should also be exposed to adult learning principles (andragogy) or these classes should be handled by the teachers who have qualifications in Adult Education

2. Open learning student teacher evaluation programs should be incorporated

3. Teacher training should emphasize personal attributes when dealing with qualities of a good teacher

4. A study could be conducted to ascertain the attitude of teachers and other learners towards open learning students

\section{References:-}

1. Bullocks, M. (2015). What Makes a Good Teacher? Exploring Student and Teacher Beliefs on Good Teaching. Rising Tides vol.7 pp.1-30

2. Fosen, D.M. (2016). Developing good teacher-student relationships. A multiple case study of six teacher relational strategies and perceptions of closeness to students. London: University College.

3. Hollins E.R (2011). Teacher Preparation for Quality Teaching. Journal of Teacher Education 64(4) 395-407 SAGE

4. Kayungwa, L.J. (2002). Qualities of an Effective Teacher as Perceived by Grade 12 pupils and Teachers in selected Schools in Lusaka. Lusaka. University of Zambia

5. Kidd, J.R. (1973). How Adults Learn. Chicago: Follett Publishing Company

6. Knowles, M.S (1980). Modern Practice of Adult Education. Chicago: Follett Publishing Company

7. Lindeman, E.C (1926). The Meaning of Adult Education.New York: University Microfilms

8. Ministry of Education (2016). Educational Statistical Bulletin. Lusaka: Ministry of Education

9. Ministry of National Development Planning (2017).Seventh National Development Plan. Lusaka: Ministry of National development Planning.

10. Mutale, H. (2010). School managers, Teachers and Pupils Opinions of Effective Teachers in Selected High Schools of Lusaka Urban District. Lusaka. University of Zambia.

11. Saleemi, A.R. (undated). Qualities of a Good Teacher. Lahore: University of Engineering and Technology

12. Siaciwena, R. and Lubinda, F. (2008). The Role of Open and Distance Learning in the Implementation of the Right to Education in Zambia. IRRODL, vol 9 No.1

13. Walker R.J (2008). Twelve Characteristics of an Effective Teacher. Alabama: State University.www.phoenix.ed 